\title{
EFFECT OF COMPOST APPLICATION ON SOME PROPERTIES OF A VOLCANIC SOIL FROM CENTRAL SOUTH CHILE
}

\author{
Pedro José Valarini', Gustavo Curaqueo², Alex Seguel², Karina Manzano², Rosa Rubio², Pablo \\ Cornejo ${ }^{2}$, and Fernando Borie ${ }^{2 *}$
}

\begin{abstract}
Soil compost application is a common soil management practice used by small farmers of Central-South Chile that produces positive effects on soil properties and also promotes presence and activity of arbuscular mycorrhizal fungi (AMF). This fungi form symbiosis with plant roots improving plant nutrition, as well as producing glomalin, a glycoprotein that has been associated with soil aggregation stability. Therefore, the aim of this study was to evaluate, in an Ultisol from Central-South Chile, the effect of different doses of compost on some soil characteristics at the end of the third year of a crop sequence including wheat (Triticum aestivum L.), bean (Phaseolus vulgaris L.), and grassland (Lolium multiflorum Lam. associated with Trifolium repens L.). Studied soil characteristics included chemical ( $\mathrm{pH}$, available-P, organic $\mathrm{C}$ ), biological ( $\mathrm{C}$ and $\mathrm{N}$ biomass, $\mathrm{AMF}$ spore number, root colonization percentage, mycelium length, and glomalin content), as well as physical parameters (water holding capacity [WHC], and water stable aggregates [WSA]). Results showed that, in general, compost application increased soil $\mathrm{pH}$, mycorrizal roots, mycelium length, glomalin levels, and WSA. Significant relationships were found between C and $\mathrm{N}$ biomass, $\mathrm{C}$ biomass and WSA, $\mathrm{C}$ biomass and glomalin, WSA and WHC, among others. Results suggest that compost application to this type of soil is a feasible option as a fertilizer substitute, and a way to avoid soil erosion by small local farmers involved in organic agriculture.
\end{abstract}

Key words: compost, glomalin, soil aggregation, Ultisol.

\section{INTRODUCTION}

Conservation agriculture systems using a low level of external inputs have become more important worldwide in the last few years since they promote the preservation of natural resources, reducing ecosystem degradation, both natural and agroecosystems (Mäder et al., 2002; Francis and Daniel, 2004). Within this context, organic agriculture promotes the use of agronomic practices and alternative technologies in accordance with the socioeconomic and ecological conditions of the zone where the productive system is located, in particular as it refers to fertilization, which is usually carried out by applying organic materials such as manure, plant residues, or compost, much of which are produced inside the same farm (Shannon et al., 2002). Applying organic materials to crop soil not only generates a better nutritional state, but furthermore, positively influences other properties, such as soil particles

'EMBRAPA Meio Ambiente, Rodovia SP 340, km 127,5, Caixa Postal 69, Jaguariúna, São Paulo, Brasil.

${ }^{2}$ Universidad de La Frontera, Facultad de Ingeniería, Ciencias y Administración, Casilla 54-D, Temuco, Chile. *Corresponding author (fborie@ufro.cl).

Received: 07 March 2008.

Accepted: 03 August 2008. aggregation, water holding capacity and aeration (Pagliai et al., 2004), contributing to generating high production, even with a low or nil application of fertilizers.

On the other hand, in aspects normally considered in the conservation agriculture systems, the use of distinct plant species are found in crop rotation, or the use of associated crops (Francis and Daniel, 2004). Among other species, the use of legumes is emphasized, which can favor the incorporation of $\mathrm{N}$ to the productive system, reducing in this way the probable negative balance caused by the low or nil external contribution of this element via fertilizers (Oehl et al., 2002; 2004).

Another important contribution to soil quality improvement using conservation practices based on the use of organic substances like compost is the beneficial effect on growth, diversity, and activity of diverse groups of rhizospheric microorganisms that promote plant growth (Oehl et al., 2004; Gosling et al., 2006). In particular, the arbuscular mycorrhizal fungi (AMF) become relevant in this type of productive systems, since the symbiosis that they establish with the roots of most of the species of terrestrial plants contribute to increase $\mathrm{P}$ absorption from the soil, as well as other elements with limited availability for the plants (Clark and Zeto, 2000; Cornejo et al., 2008b). With this, AMF contribute decisively in neutralizing the 
negative balance in $\mathrm{P}$ availability that probably could be found in this type of agricultural systems due to the greater external contribution of fertilizers (Scullion et al., 1998; Oehl et al., 2002).

Presence of AMF does not only result crucial in conservation agriculture systems for its contribution to plant nutrition, but furthermore, because the establishment of the arbuscular mycorrhiza (AM) favors growth of the bacterial microflora adjacent to the fungus hyphae, accelerating its metabolic activity and nutrient cycle (Barea et al., 2005). On the other hand, numerous studies show that implementing conservation agriculture production systems favors root AM colonization of the cultivated plants and increases the number of species of this type of fungi that make up their communities in the soil and inside the roots (Mäder et al., 2000; Jansa et al., 2002; Oehl et al., 2003; 2004). In addition, AMF can directly favor the formation of stable soil aggregates through the extension of the hyphal network that entangles small particles, and indirectly through glomalin accumulation, a glycoprotein produced by AMF and liberated into the soil in considerable quantities (Rillig, 2004; Driver et al., 2005). Glomalin, due to its recalcitrance, hydrophobicity, and adhesiveness play an important role as cementing material of the soil particles, at the same time acting as a highly stable form of organic $\mathrm{C}$ storage that could represent an important fraction of the total organic matter of the soil (Morales et al., 2005; Rillig and Mummey, 2006; Cornejo et al., 2008a).

Considering the growing interest for the use of conservation agriculture systems, like those that use compost as the basis of fertilization, it becomes necessary to study the effect of its addition on the persistence and functionality of microbial groups relevant in these systems, like AMF, and their joint effect on the variations of physical and chemical soil characteristics. Therefore, the objective of this study was to analyze the effect of applying increasing doses of compost in some physicalchemical properties of an Ultisol of the central-southern zone of Chile, its relation with the persistence of AMF propagules and the functionality of the established AM symbiosis, determined as the accumulation of glomalin. For this, a cultivated soil was used with rotations simulating an organic agricultural system, adding compost in greenhouse-controlled conditions, including wheat (Triticum aestivum L.), bean (Phaseolus vulgaris L.), and grassland (Lolium multiflorum Lam. associated with Trifolium repens L.) as the fist crop of 3-year rotation.

\section{MATERIALS AND METHODS}

\section{Experimental design}

The experimental design was completely randomized and treatments consisted in a simulation of crop rotation sequences where the influential variable was the first crop from each one of the simulations (grassland, wheat, or bean). Each year, the grassland assay was maintained approximately 7 months, bean was harvested at physiological maturity, and wheat at mature grain stage (Zadocks 91; Zadocks et al., 1974). Results given here correspond to those obtained at the end of the 3 -year rotation cycle where evidently, the last of these crops affected more the studied soil characteristics, especially biological (Millaleo et al., 2006). In each one of the treatments, for each dose of compost, five replicates were used $(n=60)$.

\section{Crop conditions}

The assay was carried out in the greenhouses of the Universidad de La Frontera (Temuco, Chile), for 3 consecutive years. To $5 \mathrm{~L}$-capacity pots containing soil sampled at 0-10 cm (Ultisol, Metrenco series, fine, mesic, Palehumult) from a natural prairie ( $\left.38^{\circ} 41^{\prime} \mathrm{S} ; 72^{\circ} 35^{\prime} \mathrm{W}\right)$, increasing doses of compost 8,20 , and $30 \mathrm{Mg} \mathrm{ha}^{-1} \mathrm{yr}^{-1}$ $\left(\mathrm{D}_{8}, \mathrm{D}_{20}, \mathrm{D}_{30}\right)$, including a control without application $\left(\mathrm{D}_{0}\right)$ were artificially added. The applied compost was prepared at the Centro de Enseñanza y Tecnología (CETSur, Temuco), with agricultural plant waste and animal beds based on cow manure and wheat straw. The initial soil chemical characteristics of the soil and compost used (Table 1) were determined by analysis methodologies proposed by Sadzawka et al. $(2005 ; 2006)$ for compost and soils in Chile.

The following crops were used as AMF hosts in a sequential form and in the way they are normally used by small farmers: a) grassland, b) bean (cv. Negro Argel), and c) wheat (cv. Paleta). Seeds provided by CET-Sur from organic production were used for each crop. Sowing of the grassland was carried out with L. multiflorum L. and T. repens L. in seed doses equivalent to 20 and $8 \mathrm{~kg}$ $\mathrm{ha}^{-1}$, respectively. In bean and wheat, the seed doses were 100 and $120 \mathrm{~kg} \mathrm{ha}^{-1}$, with a plant density of 3 and 10 plants pot $^{-1}$, respectively, while in the grassland, the seed density was associated with the equivalence of field sowing and was carried out manually. During the whole assay, plants grew in greenhouse conditions (16:8 h light/darkness; $25 / 15{ }^{\circ} \mathrm{C}$ day/night), irrigation was carried out manually with potable water, maintaining constant humidity for weight. All pots were manually weeded.

\section{Measurements}

Soil $\mathrm{pH}$ was measured potentiometrically with glass electrode in a mixture of soil:water at ratio of 1:2.5 w/v. Available $\mathrm{P}$ was measured spectrophotometrically after its extraction from the soil with a $\mathrm{NaHCO}_{3} 0.5 \mathrm{M}$ solution at pH 8.5 (Olsen and Sommers, 1982), and soil organic C (SOC) was determined by the humid oxidation method 
Table 1. Chemical characteristics of soil and compost used in this study.

\begin{tabular}{|c|c|c|}
\hline Parameter & Soil $(0-10 \mathrm{~cm})$ & Compost \\
\hline Organic matter, $\%$ & 6.20 & 25.7 \\
\hline $\mathrm{pH}$ & 5.67 & 7.97 \\
\hline Total N, \% & 0.30 & 0.99 \\
\hline P-Olsen, $\mathrm{mg} \mathrm{kg}^{-1}$ & 15.60 & 441 \\
\hline $\mathrm{K}, \mathrm{mg} \mathrm{kg}^{-1}$ & 82.0 & 8.73 \\
\hline Humidity, \% & 14.3 & 68.2 \\
\hline $\mathrm{K}, \mathrm{cmol}+\mathrm{kg}^{-1}$ & 0.21 & 22.3 \\
\hline $\mathrm{Na}, \mathrm{cmol}+\mathrm{kg}^{-1}$ & 0.08 & 2.83 \\
\hline $\mathrm{Ca}, \mathrm{cmol}+\mathrm{kg}^{-1}$ & 5.12 & 22.4 \\
\hline $\mathrm{Mg}, \mathrm{cmol}+\mathrm{kg}^{-1}$ & 1.29 & 9.90 \\
\hline $\mathrm{Al}, \mathrm{cmol}+\mathrm{kg}^{-1}$ & 0.13 & 0.02 \\
\hline Al saturation, $\%$ & 1.90 & 0.03 \\
\hline $\mathrm{ECEC}, \mathrm{cmol}+\mathrm{kg}^{-1}$ & 6.83 & 57.5 \\
\hline Sum of bases, cmol $+\mathrm{kg}^{-1}$ & 6.70 & 57.5 \\
\hline
\end{tabular}

ECEC: effective cation exchange capacity.

and Walkley and Black (1974) titration. The number of AMF spores in the soil was quantified on a Doncaster plate under a stereoscopic microscope at 20-40X, after its separation from the soil by wet sieving and decanting (Sieverding, 1991). The colonization percentage for AMF was determined by the line intercept method (Tennant, 1975) after dyeing root segments with tripane blue in accordance with the methodology described by Phillips and Hayman (1970). The length of the total AMF mycelium was determined by the line intercept method after its extraction from $3 \mathrm{~g}$ of soil with hot glycerine acid in accordance with the technique modified for volcanic soils proposed by Rubio et al. (2003). Glomalin fractions (operationally defined as glomalin related soil protein [GRSP]), total GRSP, and easily extractable GRSP (EEGRSP) were determined in accordance with the method described by Wright and Upadhyaya (1996; 1998), after its extraction from the soil with sodium citrate buffer and autoclave sterilization at $121{ }^{\circ} \mathrm{C}$. For EE-GRSP, a citrate buffer $20 \mathrm{mM}$ at $\mathrm{pH} 7.0$, autoclave sterilization for 30 $\mathrm{min}$, and centrifuged at $3000 \mathrm{rpm}$ for $15 \mathrm{~min}$ were used. This fraction is considered as the most recent glomalin production (Lovelock et al., 2004), and therefore of lower recalcitrance. Total GRSP was extracted by carrying out sterilization cycles in autoclave for $60 \mathrm{~min}$ with a citrate buffer $50 \mathrm{mM}$ at $\mathrm{pH} 8.0$, and subsequent centrifugation at $3000 \mathrm{rpm}$ for $15 \mathrm{~min}$. Quantification of GRSP and EEGRSP was carried out with the Bradford method of total protein measurement. The percentage of water stable aggregates (WSA, 1-2 mm class aggregate measurement) was determined by wet sieving method (Kemper and Rosenau, 1986), and maximum water holding capacity (WHC) according to the methodology described by Zagal et al. (2003). The $\mathrm{C}$ and $\mathrm{N}$ of the microbial biomass were determined by the fumigation/extraction method by Vance et al. (1987) and Joergensen (1998), respectively.

\section{Statistical analysis}

Statistical analysis was carried out by means of the SPSS v.14 software (Visauta, 2007). Data were submitted to a normality test before analysis of variance. When statistical significance was found $(\mathrm{P} \leq 0.05)$, comparison of the means was carried out by using the Tukey test. Furthermore, a Pearson $r$ correlation analysis was carried out to observe the degree of association between some of the studied variables.

\section{RESULTS AND DISCUSSION}

\section{Variation of the analyzed chemical properties}

The effect of applying different doses of compost in $\mathrm{pH}$, P-Olsen, organic C, and WHC of the soil are shown in Table 2. Adding compost increased $\mathrm{pH}$ levels, especially at doses equivalent to 20 and $30 \mathrm{Mg} \mathrm{ha}^{-1}$. Crops that showed a greater $\mathrm{pH}$ increase were wheat and grassland $(\mathrm{P} \leq 0.05)$, while there were no significant differences in bean. In general, the order of $\mathrm{pH}$ increase was grassland $>$ wheat $>$ bean. Such an increase in $\mathrm{pH}$ levels in soils with added compost is widely reported in the literature (Castillo et al., 2004; Buttler and Muir, 2006), and could be the consequence, of an increase of exchangeable bases with a concomitant decrease in polycation levels ( $\mathrm{Fe}$ and $\mathrm{Al}$, Table 1) due to the complex capacity of the compost humic acids (Bulluck et al., 2002) and soil stabilization by an increase and/or maintenance of its buffer capacity (Leifeld et al., 2002), among others. 
Table 2. Effect of compost application on soil pH, P-Olsen, organic C, and water holding capacity (WHC) at the third year of a three-crop rotation.

\begin{tabular}{|c|c|c|c|c|c|}
\hline Crops & Compost & pH & P-Olsen & Organic C & WHC \\
\hline \multirow{5}{*}{ Wheat } & $\mathrm{Mg} \mathrm{ha}^{-1}$ & $1: 2.5$ & $\mathrm{mg} \mathrm{kg}^{-1}$ & $\%$ & $\%$ \\
\hline & 0 & $5.5 \mathrm{bA}$ & $6.2 \mathrm{cC}$ & $3.7 \mathrm{aA}$ & $65.4 \mathrm{aA}$ \\
\hline & 8 & $5.3 \mathrm{bA}$ & $8.1 \mathrm{bC}$ & $3.7 \mathrm{aA}$ & $60.2 \mathrm{bA}$ \\
\hline & 20 & $6.1 \mathrm{aA}$ & $13.3 \mathrm{aA}$ & $4.2 \mathrm{aA}$ & $65.9 \mathrm{aA}$ \\
\hline & 30 & 5.8abAB & $17.3 \mathrm{aA}$ & $4.4 \mathrm{aA}$ & - \\
\hline \multirow{4}{*}{ Bean } & 0 & $5.5 \mathrm{aA}$ & 17.3abA & $3.4 \mathrm{aA}$ & $64.5 \mathrm{aA}$ \\
\hline & 8 & $5.5 \mathrm{aA}$ & $21.1 \mathrm{aA}$ & $3.5 \mathrm{aA}$ & $64.3 \mathrm{aA}$ \\
\hline & 20 & $5.8 \mathrm{aA}$ & $12.9 \mathrm{bA}$ & $3.5 \mathrm{aAB}$ & $69.8 \mathrm{aA}$ \\
\hline & 30 & $5.8 \mathrm{aAB}$ & 17.3abA & $3.9 \mathrm{aB}$ & - \\
\hline \multirow{4}{*}{ Grassland } & 0 & $5.5 \mathrm{bA}$ & $12.4 \mathrm{aB}$ & $3.1 \mathrm{aA}$ & $60.3 \mathrm{aA}$ \\
\hline & 8 & $5.8 \mathrm{abA}$ & $11.4 \mathrm{aB}$ & $2.9 \mathrm{aB}$ & $59.7 \mathrm{aA}$ \\
\hline & 20 & $6.3 \mathrm{aA}$ & $13.1 \mathrm{aA}$ & $3.3 \mathrm{aB}$ & $62.1 \mathrm{aA}$ \\
\hline & 30 & $6.3 \mathrm{aA}$ & $16.9 \mathrm{aA}$ & $3.1 \mathrm{aC}$ & - \\
\hline
\end{tabular}

Different lowercase letter in the same crop and capital letters for equal doses indicate significant differences according to the Tukey test (P $\leq 0.05)$.

Along this line, Castillo et al. (2004) reported increases of up to 0.34 units of $\mathrm{pH}$ when applying compost for 2 consecutive years in an Ultisol of the same series used in this study.

Although compost addition did not produce an increase in SOC levels as reported by other studies (Celik et al., 2004; Wahba, 2007), significant differences were observed with respect to the effect of the crop used. This is how bean and grassland were associated with a decrease of $\mathrm{C}$ levels, which would be suggesting a mineralization stimulation of SOC, especially in grassland.

On the other hand, differences in P availability when adding compost were not observed, with the exception of the treatment using wheat as the last crop of the rotation, probably as a consequence of the initial $\mathrm{P}$ content. The former would be related with a greater mineralization of organic $\mathrm{P}$, in this case with no major variation in its levels in spite of consumption by the crop. This type of soil has high levels of total $\mathrm{P}$, of which more than $50 \%$ is found under potentially mineralizable organic forms (Borie and Rubio, 2003).

\section{Effect of compost on AMF propagules, GRSP accumulation, and microbial biomass}

The effect of adding compost on the fungal parameters, such as the number of spores remaining in the soil at the end of the cycle, root colonization, and the length of fungal mycelium are shown in Table 3, together with the $\mathrm{C}$ and $\mathrm{N}$ values of the microbial biomass.

All crops used in the rotation were susceptible to developing arbuscular mycorrhiza for which it was expected that the number of spores would not vary significantly towards the end of the third year of the crop when all systems completed the rotation cycle as shown in Table 3. These results are in accordance with those obtained by Millaleo et al. (2006), who did not observe differences in this type of propagules in the second rotation year in a system similar to the one studied. Notwithstanding the aforementioned, the root colonization observed in this study was greater in wheat and grassland with respect to that observed in the case of bean, increasing such a colonization as the dose of compost increases, especially at $D_{20}$ and $D_{30}$ doses (Table 3 ), coinciding with the tendency pointed out by Sattelmacher et al. (1991); Ryan et al. (1994), and more recently by Mäder et al. (2000), who reported an increase between 30 and $60 \%$ in mycorrhization with compost application. These last authors conclude that approximately $50 \%$ of such an increase was due to the benefits produced by the compost in the levels of $\mathrm{pH}, \mathrm{K}$, and fundamentally, P soluble, effect which, in this study only was observed in wheat.

There is evidence that in agricultural systems with low external input contributions, as is organic agriculture, plants can benefit through the symbiotic mycorrhizal activity which increases the capacity to acquire nutrients from the soil at low concentrations (Oehl et al., 2002). In this way, significant increases in root colonization in rye (Secale cereale L.) (Sattelmacher et al., 1991) and winter wheat (Ryan et al., 1994) have been reported in organically fertilized systems compared to conventional systems, suggesting that the quantity of $\mathrm{P}$ soluble is the main cause of such differences (Mäder et al., 2000). Although it is known that the greater availability of $\mathrm{P}$ inhibits the formation and functionality of mycorrhizal symbiosis, 
decreasing the number of propagules remaining in the soil at the end of the crop cycle, the contribution of compost to the different systems did not increase available $\mathrm{P}$, but produced a beneficial effect on AM colonized roots. This greater colonization will be associated with a greater number of potentially infective propagules in the soil which would produce an earlier colonization of the following crop in the rotation system. Notwithstanding the aforementioned, the length of the extraradical mycelium decreased with compost application in wheat and grassland, without registering a correlation between the density of this propagule and root colonization (Table 4), which differ with that reported in other more arid soils and basic $\mathrm{pH}$ over 8.0 (Labidi et al., 2007).

Compost addition significantly increased microbial activity, expressed through the contents of the $\mathrm{C}$ and $\mathrm{N}$ biomass (Borken et al., 2002), which furthermore showed a highly significant correlation $(r=0.701)$. Other important correlations were those between $\mathrm{pH}$ and $\mathrm{C}$ biomass $(r=0.676)$, and $\mathrm{pH}$ with $\mathrm{N}$ biomass $(r=0.463)$ (Table 4$)$. The close relationship between fungal mycelium and microbial biomass expressed through $\mathrm{C}(r=0.499)$ or $\mathrm{N}$ bioamass $(r=0.465)$ suggests that in these systems, AMF hyphae can make up a high proportion of total microbial biomass. On the other hand, the correlation found between fungal mycelium and GRSP $(r=0.436 ; \mathrm{P}<0.01)$ would be confirming that this glycoprotein is part of the walls of AMF hyphae, as indicated by Driver et al. (2005).
With the exception of that observed in the grassland crop, adding compost increased GRSP content in the rest of the crops, especially with increasing doses of compost (Figure 1A), although no differences were observed in EE-GRSP levels (Figure 1B).

Although the increase of glomalin levels is usually related to greater AMF activity in systems with organic substances (Oehl et al., 2004), or adding organic nutrient sources, such as cattle manure, compost, and crop stubble, which significantly stimulate mycorrhizal development (Harinikumar and Bagyaraj, 1989; Douds et al., 1997; Joner, 2000; Castillo et al., 2004), the increase of glomalin levels could be due to interferences produced by determining protein by the Bradford reactive, effect that has recently been demonstrated when significant quantities of some organic materials are added to soils (Rosier et al., 2006).

\section{Effect of adding compost on some physical properties}

Even if an increase in WHC was expected by adding compost, this parameter was not significantly affected neither by increasing quantities of compost added nor crop type (Table 2). Although there is background information that points out a positive effect of compost on water holding capacity of saline soils (Zebarth et al., 1999; Carter et al., 2004) or in semiarid soils (Celik et al., 2004), there is no information that points out an increase in this property in soils with medium to high soil organic matter (SOM) content by adding compost for short periods as was the case in this study.

Table 3. Effect of compost application on mycorrhizal spore number, root colonization percentage, fungal mycelium length, and $\mathrm{C}$ and $\mathrm{N}$ biomass at the third year of a three crop rotation.

\begin{tabular}{|c|c|c|c|c|c|c|}
\hline Crops & Compost & Spores & $\begin{array}{c}\text { Root } \\
\text { colonization }\end{array}$ & $\begin{array}{c}\text { AMF } \\
\text { mycelium } \\
\text { length }\end{array}$ & $\underset{\text { biomass }}{\mathrm{C}}$ & $\begin{array}{c}\mathrm{N} \\
\text { biomass }\end{array}$ \\
\hline \multirow{5}{*}{ Wheat } & $\mathrm{Mg} \mathrm{ha}^{-1}$ & $\mathrm{~N}^{\circ} \mathrm{g}^{-1} \mathrm{ds}$ & $\%$ & $\mathrm{~m} \mathrm{~g}^{-1}$ & \multicolumn{2}{|c|}{$\longrightarrow \mathrm{mg} \mathrm{kg}^{-1}$} \\
\hline & 0 & $1366 \mathrm{aA}$ & $48.2 \mathrm{bA}$ & $1.2 \mathrm{abB}$ & $275.69 \mathrm{cB}$ & $30.20 \mathrm{bA}$ \\
\hline & 8 & $1926 \mathrm{aA}$ & $47.2 \mathrm{bA}$ & $1.4 \mathrm{aA}$ & $325.81 \mathrm{bB}$ & $37.16 \mathrm{bA}$ \\
\hline & 20 & $1310 \mathrm{aB}$ & $64.6 \mathrm{aA}$ & $1.5 \mathrm{aB}$ & $482.77 \mathrm{aB}$ & $47.94 \mathrm{aA}$ \\
\hline & 30 & $2986 \mathrm{aA}$ & $64.6 \mathrm{aA}$ & $0.6 \mathrm{bC}$ & - & - \\
\hline \multirow{4}{*}{ Bean } & 0 & $2790 \mathrm{aA}$ & $7.5 \mathrm{bB}$ & $2.1 \mathrm{aA}$ & $314.78 \mathrm{cA}$ & $34.96 \mathrm{aA}$ \\
\hline & 8 & $2390 \mathrm{aA}$ & $18.3 \mathrm{aB}$ & $1.3 \mathrm{aA}$ & $350.13 \mathrm{bB}$ & $35.68 \mathrm{aA}$ \\
\hline & 20 & $2051 \mathrm{aAB}$ & $10.8 \mathrm{abC}$ & $1.8 \mathrm{aB}$ & $499.97 \mathrm{aB}$ & $45.11 \mathrm{aA}$ \\
\hline & 30 & $2141 \mathrm{aA}$ & $37.4 \mathrm{aB}$ & $1.7 \mathrm{aB}$ & - & - \\
\hline \multirow{4}{*}{ Grassland } & 0 & $1502 \mathrm{aA}$ & $42.6 \mathrm{aA}$ & $2.2 \mathrm{bA}$ & $259.73 \mathrm{cB}$ & $33.02 \mathrm{bA}$ \\
\hline & 8 & $2031 \mathrm{aA}$ & $46.0 \mathrm{aA}$ & $2.3 \mathrm{bA}$ & $383.93 \mathrm{bA}$ & $36.92 \mathrm{bA}$ \\
\hline & 20 & $2285 \mathrm{aA}$ & $51.6 \mathrm{aB}$ & $6.3 \mathrm{aA}$ & $538.97 \mathrm{aA}$ & $51.05 \mathrm{aA}$ \\
\hline & 30 & $1956 \mathrm{aA}$ & $54.7 \mathrm{aA}$ & $2.8 \mathrm{bA}$ & - & - \\
\hline
\end{tabular}

Different lowercase letter in the same crop and capital letters for equal doses indicate significant differences according to the Tukey test (P $\leq 0.05$ ). $\mathrm{N}^{\mathrm{o}} \mathrm{g}^{-1} \mathrm{ds}$ : Number per gram of dry soil; AMF: arbuscular mycorrhizal fungi. 
Table 4. Correlation matrix for some of the evaluated parameters.

\begin{tabular}{lcccccc}
\hline Parameter & Colonization & WHC & P-Olsen & Mycelium & C biomass & N biomass \\
\hline pH & $0.296^{*}$ & $\mathrm{~ns}$ & $\mathrm{~ns}$ & $0.448^{* *}$ & $0.676^{* *}$ & $0.463^{* *}$ \\
EE-GRSP & $0.358^{*}$ & $\mathrm{~ns}$ & $-0.404^{*}$ & $\mathrm{~ns}$ & $\mathrm{~ns}$ & $\mathrm{~ns}$ \\
GRSP & $\mathrm{ns}$ & $\mathrm{ns}$ & $\mathrm{ns}$ & $0.436^{* *}$ & $0.349 *$ & $0.461 * *$ \\
WSA & $\mathrm{ns}$ & $0.396^{*}$ & $\mathrm{~ns}$ & $\mathrm{~ns}$ & $0.570^{* *}$ & $0.445^{* *}$ \\
Mycelium & $\mathrm{ns}$ & $\mathrm{ns}$ & $\mathrm{ns}$ & 1 & $0.499 * *$ & $0.465^{* *}$ \\
C biomass & $\mathrm{ns}$ & $\mathrm{ns}$ & $\mathrm{ns}$ & $0.499 * *$ & 1 & $0.701 * *$ \\
N biomass & $\mathrm{ns}$ & $\mathrm{ns}$ & $\mathrm{ns}$ & $0.465^{* *}$ & $0.701^{* *}$ & 1 \\
\hline
\end{tabular}

*Correlation significant at 0.05 . **Correlation significant at 0.01 .

ns: not significant $(\mathrm{n}=36)$; EE-GRSP: easily extractable glomalin; GRSP: total glomalin; WSA: water stable aggregates; WHC: water holding capacity.

On the other hand, an increase was observed in WSA with compost application, especially with the highest doses (Figure 2), effect that has also been observed when adding composted organic materials to the soil in other studies (Medina et al., 2004; Caravaca et al., 2006; Annabi et al., 2007; Wortmann and Shapiro, 2008). In our study, this can be due to the greater glomalin levels found at the highest doses of compost application (Figure 1A).

Although other studies have found significant correlations between soil aggregate stability and GRSP (Rillig et al., 2002; Rillig, 2004; Wright et al., 2007), the level of such protein appears to be rather dependent on the AMF plant host species (Rillig et al., 2002), establishing that stability of soil aggregates is more dependent on the quantity of GRSP than the length of the network of AMF hyphae found. The results reported here suggest this same tendency. Thus, while in general, adding compost did not affect the external mycelium length (effect on physical bonding of particles), increasing doses of compost stimulated GRSP production (effect of cementing particles).

It is important to point out that $\mathrm{C}$ and $\mathrm{N}$ associated to glomalin represent a very important fraction of the total $\mathrm{C}$ and $\mathrm{N}$ content that these soils contain. Thus, $\mathrm{C}$ in the studied soil and adding compost in increasing doses fluctuated between 7.6 and $17.5 \%$, and $\mathrm{N}$ between 13.5 and $31.1 \%$ (Table 5).

These values are quite a bit higher than those reported by Lovelock et al. (2004), who reported a mean of 3.2\% for C-GRSP and 5\% for N-GRSP of total $\mathrm{C}$ and $\mathrm{N}$ present in Ultisols of the tropical forests in Costa Rica. In the same way, C-GRSP levels found in this study exceed those reported by Borie et al. (2006) in Ultisol in the South of Chile, cultivated and managed with distinct tillage systems (4.6 to $5.0 \%$ ), but were significantly lower than those reported by Morales et al. (2005) in forested Andisols of the Los Lagos Region (18.5-26.1\%), and Seguel et al. (2008) in forested soils of the La Araucanía
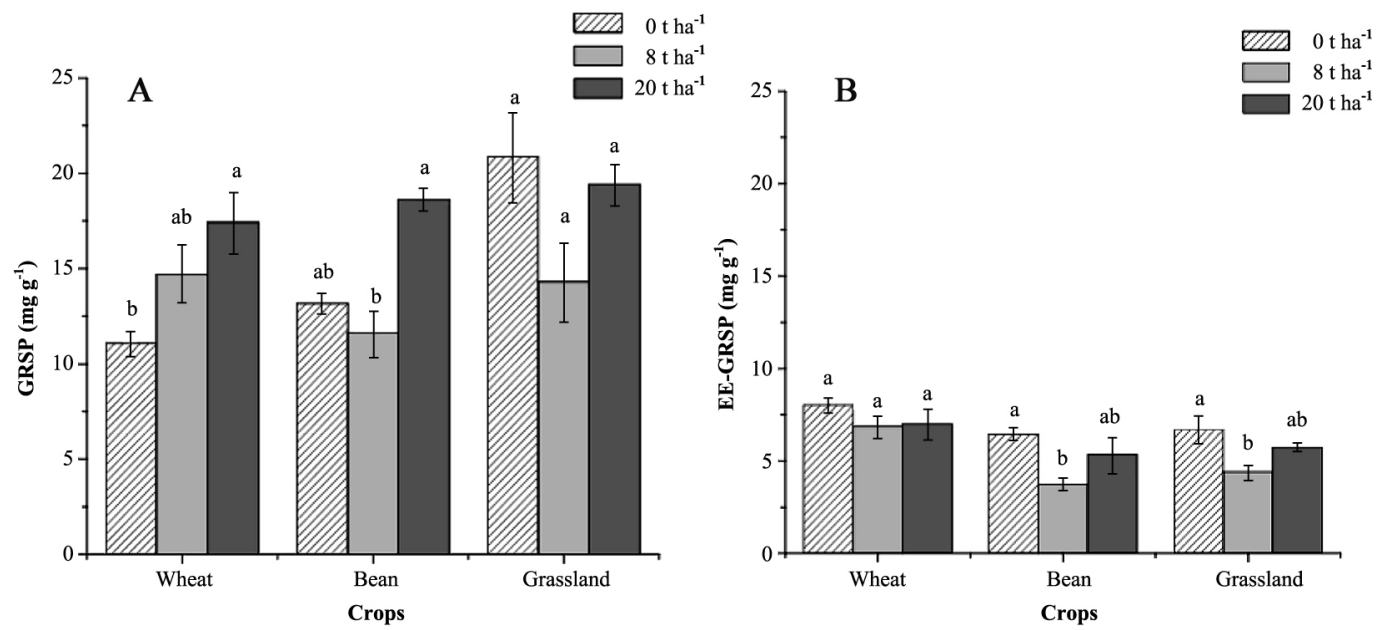

Figure 1. Effect of compost application on total glomalin content (GRSP, A) and easily extractable glomalin (EE-GRSP, B) at the end of the third year of a three crop rotation. 
Table 5. Glomalin $\mathrm{C}$ and $\mathrm{N}$ contribution to total soil $\mathrm{C}$ and $\mathrm{N}$ pools.

\begin{tabular}{|c|c|c|c|}
\hline \multirow[t]{3}{*}{ Crops } & Compost & C-GRSP & N-GRSP \\
\hline & $\mathrm{Mg} \mathrm{ha}^{-1}$ & -0 & \\
\hline & 0 & $9.4 \mathrm{bB}$ & $16.3 \mathrm{bC}$ \\
\hline \multirow[t]{3}{*}{ Wheat } & 8 & $13.5 \mathrm{abA}$ & $23.7 \mathrm{aA}$ \\
\hline & 20 & $14.5 \mathrm{aB}$ & $25.6 \mathrm{aB}$ \\
\hline & 0 & $16.3 \mathrm{aA}$ & $27.4 \mathrm{bB}$ \\
\hline \multirow[t]{3}{*}{ Bean } & 8 & 7.6bB & $13.5 \mathrm{cC}$ \\
\hline & 20 & $16.2 \mathrm{aA}$ & $31.1 \mathrm{aA}$ \\
\hline & 0 & $17.5 \mathrm{aA}$ & $29.8 \mathrm{aA}$ \\
\hline \multirow[t]{2}{*}{ Grassland } & 8 & $12.2 \mathrm{cA}$ & $21.0 \mathrm{cB}$ \\
\hline & 20 & $14.8 \mathrm{bB}$ & $26.9 \mathrm{bB}$ \\
\hline
\end{tabular}

Calculated on the basis of $\mathrm{C}$ and $\mathrm{N}$ glomalin content $(30$ and $5 \%$, respectively; Etcheverría, 2008. Universidad de La Frontera. Personal communication). C-GRSP: C associated to glomalin. N-GRSP: N associated to glomalin.

Different lowercase letter in the same crop and capital letters for equal doses indicate significant differences according to the Tukey test $(\mathrm{P} \leq$ $0.05)$.

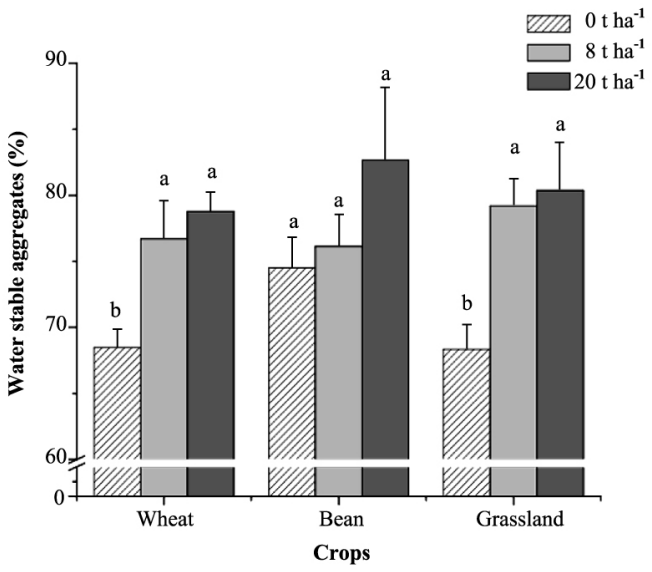

Different letters in the same crop indicate significant differences according to Tukey test $(\mathrm{P} \leq 0.05)$.

Figure 2. Effect of compost application on aggregate stability at the end of the third year of a three crop rotation.

Region, Chile (8.3-10.4\%). Hence, this study highlight the importance of deeping in the studies related to the contribution of $\mathrm{C}$ and $\mathrm{N}$ for this glycoprotein in temperate volcanic soils in Chile, rich in SOM, especially for the effect that this fraction could have in the sequestration of atmospheric $\mathrm{C}$.

\section{CONCLUSIONS}

Adding compost in volcanic soil during 3 years in a wheat, bean, and grassland rotation, improved some properties of the volcanic soil used, finding correlations between fungal mycelium, glomalin, and water stable aggregates, in which case it is concluded that AMF fulfill an important function in these systems benefitting soil structure. Hence, the suggestion that it is necessary to study in greater depth and in field conditions, the effect of adding composted materials on soil stability, especially in those with slopes susceptible to be easily eroded.

\section{ACKNOWLEDGEMENTS}

The authors thank EMBRAPA for financing the postdoctoral stay of the first author at the Universidad de La Frontera, and the FONDECYT Project 1060372.

\section{RESUMEN}

Efecto de la aplicación de compost sobre algunas propiedades de un suelo volcánico de la Región centrosur de Chile. La aplicación de compost al suelo, práctica habitual en predios de pequeños agricultores de la región centro-sur de Chile, produce efectos positivos en sus propiedades y promueve la presencia y actividad de los hongos micorrícicos arbusculares (AMF). Estos hongos forman simbiosis con las raíces de las plantas mejorando su nutrición y además producen una glicoproteína llamada glomalina, la cual ha sido relacionada con la estabilidad de los agregados de suelo. Por lo anterior, el objetivo de este estudio fue evaluar el efecto de la aplicación de distintas dosis de compost sobre algunos parámetros de un Ultisol de la zona centro-sur de Chile, al finalizar el tercer año de una secuencia de cultivos formada por trigo (Triticum aestivum L.), frejol (Phaseolus vulgaris L.) y pradera permanente (Lolium multiflorum Lam. asociada con Trifolium repens $\mathrm{L}$.). Se estudiaron parámetros químicos ( $\mathrm{pH}, \mathrm{C}$ orgánico, P-Olsen), biológicos (C y N biomásico, número de esporas de AMF, micorrización de raíces, longitud de micelio y niveles de glomalina), y físicos (capacidad de retención de agua, WHC, y agregados estables al agua, WSA). Los resultados mostraron que, en general, la aplicación de compost incrementó el pH, micorrización radical, niveles de glomalina, longitud del micelio fúngico y porcentaje de WSA. Se encontraron correlaciones entre $\mathrm{C}$ y N biomásico, $\mathrm{C}$ biomásico y WSA, C biomásico y glomalina, WSA y WHC. Los resultados aportan antecedentes sobre el uso beneficioso de compost como una alternativa viable de sustitución de insumos y disminución de la erosión en asentamientos de pequeños agricultores orientados a la agricultura orgánica.

Palabras clave: agregación de suelos, compost, glomalina, Ultisol. 


\section{LITERATURE CITED}

Annabi, M., S. Houot, C. Francou, M. Poitrenaud, and Y. Le Bissonnais. 2007. Soil aggregate stability improvement with urban composts of different maturities. Soil Sci. Soc. Am. J. 71:413-423.

Barea, J.M., M.J. Pozo, R. Azcón, and C. Azcón-Aguilar. 2005. Microbial co-operation in the rhizosphere. J. Exp. Bot. 56:1761-1778.

Borie, F., and R. Rubio. 2003. Total and organic phosphorus in Chilean volcanic soils. Gayana Bot. 60:69-73.

Borie, F., R. Rubio, J.L. Rouanet, A. Morales, G. Borie, and C. Rojas. 2006. Effects of tillage systems on soil characteristics, glomalin and mycorrhizal propagules in a Chilean Ultisol. Soil Tillage Res. 88:253-261.

Borken, W., A. Muhs, and F. Besse. 2002. Application of compost in spruce forests: effect on soil respiration, basal respiration and microbial biomass. For. Ecol. Manage. 159:49-58.

Bulluck, L.R., M. Brosius, G.K. Evanylo, and J.B. Ristaino. 2002. Organic and synthetic fertility amendments influence soil microbial, physical and chemical properties on organic and conventional farms. Appl. Soil Ecol. 19:147-160.

Buttler, T.J., and P.M. Muir. 2006. Dairy manure compost improves soil and increase tall wheatgrass yield. Agron. J. 98:1090-1096.

Caravaca, F., M.M. Alguacil, R. Azcón, and A. Roldán. 2006. Formation of stable aggregates in rhizosphere soil of Juniperus oxycedrus: Effect of AM fungi and organic amendments. Appl. Soil Ecol. 33:30-38.

Carter, M.R., J.B. Sanderson, and J.A. MacLeod. 2004. Influence of compost on the physical properties and organic matter fractions of a fine sandy loam throughout the cycle of a potato rotation. Can. J. Soil Sci. 84:211-218.

Castillo, C., R. Rubio, A. Contreras, y F. Borie. 2004. Hongos micorrizógenos arbusculares en un Ultisol de la IX Región fertilizado orgánicamente. Rev. Cienc. Suelo Nutr. 4(2):39-47.

Celik, I., I. Ortas, and S. Kilic. 2004. Effects of compost, mycorrhiza, manure and fertilizer on some physical properties of a Chromoxerert soil. Soil Tillage Res. 78:59-67.

Cornejo, P., S. Meier, G. Borie, M.C. Rillig, and F. Borie. 2008a. Glomalin-related soil protein in a Mediterranean ecosystem affected by a copper smelter and its contribution to $\mathrm{Cu}$ and $\mathrm{Zn}$ sequestration. Sci. Total Environ. 406:154-160.
Cornejo, P., R. Rubio, C. Castillo, R. Azcón, and F. Borie. 2008b. Mycorrhizal effectiveness on wheat nutrient acquisition in an acidic soil from Southern Chile as affected by nitrogen sources. J. Plant Nutr. 31:15551569.

Clark, R.B., and S.K. Zeto. 2000. Mineral acquisition by arbuscular mycorrhizal plants. J. Plant Nutr. 23:867902.

Douds, D.D., L. Galvez, M. Franke-Snyder, C. Reider, and L.E. Drinkwater. 1997. Effect of compost addition and crop rotation point upon VAM fungi. Agric. Ecosyst. Environ. 65:257-266.

Driver, J.D., W.E. Holben, and M.C. Rillig. 2005. Characterization of glomalin as a hyphal wall component of arbuscular mycorrhizal fungi. Soil Biol. Biochem. 37:101-106.

Francis, C.A., and H. Daniel. 2004. Organic farming. p. 77-84. Encyclopedia of soils in the environment. Elsevier, Oxford, UK.

Gosling, P., A. Hodge, G. Goodlass, and G.D. Bending. 2006. Arbuscular mycorrhizal fungi and organic farming. Agric. Ecosyst. Environ. 113:17-35.

Harinikumar, K.M., and D.J. Bagyaraj. 1989. Effect of cropping sequence, fertilizers and farmyard manure on vesicular arbuscular mycorrhizal fungi in different crops over three consecutive seasons. Biol. Fert. Soils 7:173-175

Jansa, J., A. Mozafar, T. Anken, R. Ruh, I.R. Sanders, and E. Frossard. 2002. Diversity and structure of AMF communities as affected by tillage in a temperate soil. Mycorrhiza 12:225-234.

Joergensen, R. 1998. The use of ninhydrin nitrogen reaction for estimating microbial biomass. p. 391-393. In Alef, K., and P. Nannipieri (eds.) Methods in applied soil microbiology and biochemistry. Academic Press Limited, London, UK.

Joner, E.J. 2000. The effect of long-term fertilization with organic or inorganic fertilizers on mycorrhizamediated phosphorus uptake in subterranean clover. Biol. Fert. Soils 32:435-440.

Kemper, W.D., and R.C. Rosenau. 1986. Aggregate stability and size distribution. p. 425-444. Methods of soils analysis. Part I. Physical and mineralogical methods. American Society of Agronomy, Madison, Wisconsin, USA.

Labidi, S., H. Nasr, M. Zouaghi, and H. Wallander. 2007. Effects of compost addition on extra-radical growth of arbuscular mycorrhizal fungi in Acacia tortilis ssp. raddiana savanna in a pre-Saharan area. Appl. Soil Ecol. 35:184-192. 
Leifeld, J., S. Siebert, and I. Kögel-Knabner. 2002. Changes in the chemical composition of soil organic matter after application of compost. Eur. J. Soil Sci. 53:299-309.

Lovelock, C.E., S.F. Wright, D.A. Clark, and R.W. Ruess. 2004. Soil stocks of glomalin produced by arbuscular mycorrhizal fungi across a tropical rain forest landscape. J. Ecol. 92:278-287.

Mäder, P., S. Edenhofer, T. Boller, A. Wiemken, and U. Niggli. 2000. Arbuscular mycorrhizae in a long-term field trial comparing low-input (organic biological) and high-input (conventional) farming systems in a crop rotation. Biol. Fert. Soils 31:150-156.

Mäder, P., A. Fliessbach, D. Dubois, L. Gunst, P. Fried, and U. Niggli. 2002. Soil fertility and biodiversity in organic farming. Science 296:1694-1697.

Medina, A., N. Vassilev, M. Alguacil, A. Roldán, and R. Azcón. 2004. Increased plant growth, nutrient uptake, and soil enzymatic activities in a desertified Mediterranean soil amended with treated residues and inoculated with native mycorrhizal fungi and a plant growth-promoting yeast. Soil Sci. 169:260-270.

Millaleo, R., C. Montecinos, R. Rubio, A. Contreras, y F. Borie. 2006. Efecto de la adición de compost sobre propágulos micorrícicos arbusculares en un suelo volcánico del centro sur de Chile. Rev. Cienc. Suelo Nutr. 6(3):26-39.

Morales, A., C.G. Castillo, R. Rubio, R. Godoy, J.L. Rouanet, and F. Borie. 2005. Niveles de glomalina en suelos de dos ecosistemas del Sur de Chile. Rev. Cienc. Suelo Nutr. Veg. 5(1):37-45.

Oehl, F., H.U. Tagmann, A. Oberson, J.M. Besson, D. Dubois, P. Mäder, et al. 2002. Phosphorus budget and phosphorus availability in soil under organic and conventional farming. Nutr. Cycl. Agroecosyst. 62:25-35.

Oehl, F., E. Sieverding, K. Ineichen, P. Mäder, T. Boller, and A. Wiemken. 2003. Impact of land use intensity on the species diversity of arbuscular mycorrhizal fungi in agroecosystems of Central Europe. Appl. Environ. Microbiol. 69:2816-2824.

Oehl, F., E. Sieverding, P. Mader, D. Dubois, K. Ineichen, T. Boller, and A. Wiemken. 2004. Impact of long-term conventional and organic farming on the diversity of arbuscular mycorrhizal fungi. Oecologia 138:574583.

Olsen, S.R., and M.E. Sommers. 1982. Phosphorus. In Methods of soil analysis. Part 2. Chemical and microbiological properties. Agronomy Monograph $\mathrm{N}^{\circ}$ 9. American Society of Agronomy, Madison, Wisconsin, USA.
Pagliai, M., N. Vignozzi, and S. Pellegrini. 2004. Soil structure and the effect of management practices. Soil Tillage Res. 79:131-143.

Phillips, J.M., and D.S. Hayman. 1970. Improved procedures for clearing roots and staining parasitic and vesicular arbuscular mycorrizal fungi for rapid assessment of infection. Trans. Br. Mycol. Soc. 55:158-161.

Rillig, M.C., S.F. Wright, and V.T. Eviner. 2002. The role of arbuscular mycorrhizal fungi and glomalin in soil aggregation: comparing effects of five plant species. Plant Soil 238:325-333.

Rillig, M.C. 2004. Arbuscular mycorrhizae, glomalin, and soil aggregation. Can. J. Soil Sci. 84:355-363.

Rillig, M.C., and D.L. Mummey. 2006. Mycorrhizas and soil structure. New Phytol. 171:41-53.

Rosier, C.L., A.T. Hoye, and M.C. Rillig. 2006. Glomalinrelated soil protein: Assessment of current detection and quantification tools. Soil Biol. Biochem. 38:22052211.

Rubio, R., F. Borie, C. Schalschli, C. Castillo, and R. Azcón. 2003. Occurrence and effect of arbuscular mycorrhizal propagules in wheat as affected by the source and amount of phosphorus fertilizer and fungal inoculation. Appl. Soil Ecol. 23:245-255.

Ryan, M.H., G.A. Chilvers, and D.C. Dumaresq. 1994. Colonization of wheat by VA-mycorrhizal fungi was found to be higher on a farm managed in an organic manner than on a conventional neighbor. Plant Soil 160:33-40.

Sadzawka, A., M. Carrasco, R. Grez, y M. Mora. 2005. Métodos de análisis de compost. Serie $N^{\circ} 34.142$ p. Centro Regional de Investigación La Platina, Santiago, Chile.

Sadzawka, A., M. Carrasco, R. Grez, M. Mora. H. Flores, y A. Neaman. 2006. Métodos de análisis recomendados para los suelos de Chile. Serie $\mathrm{N}^{\circ} 30.164$ p. Centro Regional de Investigación La Platina, Santiago, Chile.

Sattelmacher, B., S. Reinhardt, and A. Pomikalko. 1991. Differences in mycorrhizal colonization of rye (Secale cereale L.) grown in conventional or organic (biological-dynamic) farming systems. J. Agron. Crop Sci. 167:350-355.

Scullion, J., W.R. Eason, and E.P. Scott. 1998. The efectivity of arbuscular mycorrhizal fungi from high input conventional and organic grassland and grassarable rotation. Plant Soil 204:243-254.

Seguel, A., R. Rubio, R. Carrillo, A. Espinosa, y F. Borie. 2008. Niveles de glomalina y su relación con características químicas y biológicas del suelo (andisol) en un relicto de bosque nativo del sur de Chile. Bosque 29(1):11-22. 
Shannon, D., A.M. Sen, and D.B. Johnson. 2002. A comparative study of the microbiology of soils managed under organic and conventional regimes. Soil Use Manage. 18:274-283.

Sieverding, E. 1991. Vesicular-arbuscular mycorrhiza management in tropical agroecosystem. $371 \mathrm{p}$. Deutshe Gesellschaft Technische Zusammenarbeit (GTZ) GmbH, Eschborn, Germany.

Tennant, D. 1975. A test of modified line intersection method of measuring root length. J. Ecol. 63:9951001.

Vance, F., P. Brookes, and D. Jenkinson. 1987. Microbial biomass measurements in forest soils: The use of the chloroform fumigation-incubation method in strongly acid soils. Soil Biol. Biochem. 22:1023-1028.

Visauta, B. 2007. Análisis estadístico con SPSS 14. 281 p. McGraw-Hill/Interamericana de España, Madrid, España.

Wahba, M.M. 2007. Influence of compost on morphological and chemical properties of sandy soils, Egypt. J. Appl. Sci. Res. 3:1490-1497.

Walkley, A., and I. Black. 1974. A critical examination of rapid method for determining organic carbon in soils. Soil Sci. 63:251-254.
Wortmann, C.S., and C.A. Shapiro. 2008. The effects of manure application on soil aggregation. Nutr. Cycl. Agroecosyst. 80:173-180.

Wright, S.F., and A. Upadhyaya. 1996. Extraction of an abundant and unusual protein from soil and comparison with hyphal protein of arbuscular mycorrhizal fungi. Soil Sci. 161:575-586.

Wright, S.F., and A. Upadhyaya. 1998. A survey of soils for aggregate stability and glomalin, a glycoprotein produced by hyphae of arbuscular mycorrhizal fungi. Plant Soil 198:97-107.

Wright, S.F., V.S. Green, and M.A. Cavigelli. 2007. Glomalin in aggregate size classes from three different farming systems. Soil Tillage Res. 94:546-549.

Zadocks, J.C., T.T. Chang, and C.F. Konzak. 1974. A decimal code for the growth stages of cereals. Weed Res. 14:415-421.

Zagal, E., L. Longeri, I. Vidal, G. Hoffman, y R. González. 2003. Influencia de la adición de nitrógeno y fósforo sobre la descomposición de paja de trigo en un suelo derivado de cenizas volcánicas. Agric. Téc. (Chile) 63:403-415.

Zebarth, B.J., J.H. Neilsen, E. Hogue, and D. Neilsen. 1999. Influence of organic waste amendment on selected soil physical and chemical properties. Can. J. Soil Sci. 79:501-504. 